\title{
Analysis of Service Quality to Customer Satisfaction in Music Recording Studio
}

\author{
Harriman Samuel Saragih, Evo Sampetua Hariandja \\ Business School Management Department \\ University of Pelita Harapan \\ Tangerang, Indonesia \\ harriman.saragih@uph.edu
}

\author{
Muhril Ardiansyah \\ Business School Management Department \\ Bina Nusantara University \\ Jakarta, Indonesia
}

\begin{abstract}
Music recording studios are the primary backbone of the music industry, which has been evolving rapidly by technology through times. Most professional artists have highly customized standards in producing their artworks in the studio such as the quality of the sound engineer to prepare equipment, acoustic systems, equipment and tools, engineering sound, digital producing, and many other customizations. Meanwhile, other groups of customers - which are non-professionals - have different type of needs and tend to compare the quality of the studios one to another, such as the responsiveness of the studio staff, the equipment, or the ability of the staff to maintain good relationship to its customers. This research is aimed to analyze the aspects of service quality that can affect customers' satisfaction in the field of music recording studios, both for professional and non-professionals, using multiple regression method. The research shows that two out of five service quality factors, which are tangibles and reliability, have positive and significant relationship to customers' satisfaction.
\end{abstract}

Keywords- Music Recording Studio; Service Quality; Customer Satisfaction

\section{INTRODUCTION}

Since as early as the 1950s, developments in musical tastes and recording technologies have been challenging the economic viability of the recording studio sector of the musical economy [1]. Reviewing the Indonesian music industry, the Association of Indonesia Music Recording Industry stated that the music industry controlled $85 \%$ of creative industries in the domestic market, while the monetary value generated from this subsector reached 4.8 trillion in 2012 and five trillion rupiahs in 2013 [2]. Separately, the Director General of the Creative Economy also confirmed that the music industry has accounted for five trillion rupiahs of GDP in 2013 along with the increasing amount of business operations and labor absorption [3].

In Bandung, there are more than twenty music recording studios available both for practicing or professional music recording. For example, Aru and Studio 42 in Bandung which have facilitated some big artists such as the new rising Indonesian male singers Muhammad Tulus Rusydiand, Indonesian rising jazz guitarist star, Tesla Manaf Effendi to produce their album. These studios not only offer their service for professionals, but also to non-professionals. Students and workers are the examples that regularly visit the studio to practice for festivals, competitions or for leisure activities. Another example is the Art Sound studio in Jakarta that can facilitate the process of large-scale music instruments and voice recordings such as Twilite Orchestra under the famous composer Addie MS, and other famous name of Indonesian musician such as guitarist Tohpati and jazz drummer Yesaya Soemantri [4]. Studios above are examples of those which are able to survive in the music recording studio industry for more than fifteen years and still continue to operate and have been earning praises from major Indonesian artists through times.

In contrast with Lokananta Studio that is located in Surakarta, which was founded in 1950 earned the highest profit in 1980, is now said to be no longer competitive and tend to decrease in performances [5]. In line with the experience of a rock guitarist Kiki Pea based on his blog, he said there were four music recording studios in Blora, Central Java earlier on 2011 which were Pink, Illusion, Revolt and Mahabharata Studio. However, there are now only two studios left which are Pink Studio and Illusion Studio in the area [6]. The author sees that there are music recording studios that are able to continuously operate, while there are also studios do not able to compete in the current globalization era. From the observations, interviews, literatures, and discussions it is hypothesized that there are lack of attention from the management of the music recording studios to maintain the quality of which their customers are very concerned. This research would analyze the relationships in music recording studios in the lens of service quality and customers' satisfaction. Hence, through this study it is expected to be able to give insights to music recording studios to survive and focus on the creation of values and experiences that will be able to maintain and improve its services.

The author could hardly discover the service quality and customer satisfaction researches on music studios. Previous scholars that discuss the recording studio in terms of its service belongs to Seruni [7], "Sound Engineer Role in Improving the Quality of Production at Home Production Sound "Basement (Music and Recording Studio)". This study analyzed that there were lack of discussions, information, or researches of sound engineers in the society. Responsibilities of a Sound Engineer that could affect many albums are still rarely known; hence a more thorough observation is needed to gain more insight regarding this particular job. The objective of the research is to observe the role of a sound engineer in a production house "Basement 
Music and Recording Studio". The method used is qualitative research methods. Research tools utilized in the research are depth interview, observation. This method aims to explain the phenomenon with deep understandings. No sampling needed for this research. The researcher collected qualitative data which is data in the form of words, narratives sentences. This data relates to the categories and characteristics including historical data, cases, and individual experiences. The author sees that this type of research observed only small aspects in terms of service quality in recording studios. According to the five aspects of service quality defined by Parasuraman, et al. [8] - which are reliability, responsiveness, tangibility, empathy and assurance - this research mainly discuss the 'responsiveness' aspect which is the willingness to help customers and provide prompt services. Other scholar that observed the evolving trend of recording studios in the market - related with the aspects of service quality - is by Alexander [9] entitled, "New Technology and Market Structure: Evidence from the Music Recording Industry". Alexander sees that in the emergence and adaptation of the impact of new technology on the evolution of recording studio is largely unexplored. He also tried to explore how new technology that lowered the cost and scale of production affects the periods of de-concentration in the music recording industry by facilitating the entry of smaller new, product-innovating firms [9]. The method used in the journal was not explained by Alexander. However, the author believe that the method used in this paper are observations, discussions, interviews and from literature readings. Alexander concluded that new technology has affected two periods of significant changes in the music recording industry in which new firms producing innovative products, displaced the existing firms. This should promote greater levels of product diversity and variety in the offerings of the music recording industry. The author sees that this type of research has observed service quality in the tangible aspect of service quality in recording studios and its relationship with the market trend. Hence, according to this findings, this study will fill the research gap that previously has not been discussed

\section{LITERATURE REVIEW}

Currently in marketing, services are defined as "any act or performance one party can offer to another that is essentially intangible and does not result in the ownership of anything. Its production may or may not be tied to a physical product" [10]. The service component can be a minor or a major part of the total offering which can be distinguished into five categories of offerings: pure tangible good, tangible good with accompanying services, hybrid, major service with accompanying minor good and services, pure service [10]. On this research, the author argues that music studio is categorized as hybrid services because it involves two main aspects offered which are studio equipment and the service of its staffs. Hence, based on previous definitions about services, the author defines services as a result from supply and demand activities in the market, which one party can demand and offer to one another that may not be tied to the form of physical product.
Experts such as Crosby, defines quality as "Conformance to requirements"; Juran defines quality as "Fitness for use"; Deming on the other hand does not define quality in a single phrase, but he asserts that the quality of a product or a service can only be defined by the customer [11]. Chandrupatla [12] sees that the main point from Deming of quality by definition is "a predictable degree of uniformity and dependability with a quality standard suited to the customer". American Society for Quality defines quality as "excellence in goods and services, especially to the degree they conform to requirements and satisfy customers" [12]. Kotler defines quality as "the totality of features and characteristics of a product or service that bear on its ability to satisfy stated or implied needs" [10]. Hence, based on previous definitions about services, the author defines quality as "the totality of features and characteristics of a product or a service on which have a degree to conform the requirements that can satisfy customers".

Service quality definition has been expanding through times. Authors and managers of service firms concur that service quality involves a comparison of expectations with performance. Lewis and Booms [13] defines service quality as "a measure of how well the service level delivered matches customer expectations. Parasuraman, et al. [8] defines quality as "The differences between customer's expectations of services provider's performance and their evaluation of the services they received". Some experts such as Asubonteng, et al. [14] define quality as "the difference between customer's expectations for service performance prior to the service encounter and their perceptions of the service received". Based on previous definitions about services, the author defines service quality as "the totality of features and characteristics of a service on which have a degree to conform the requirements that can satisfy customers". The basic measurements variable for this study is adapted from Parasuraman, et al. [8]. Previous study conducted by Parasuraman, et al. [8] identified five determinants and its attributes of service quality which are reliability, responsiveness, assurance, empathy, and tangibles. Reliability is the ability to perform the promised service dependably and accurately. Responsiveness is the willingness to help customers and provide prompt services. Assurance is the knowledge and courtesy of employees and their ability to convey trust and confidence. Empathy is the provision of caring, individualized attention to customers. Tangibles are the appearance of physical facilities, equipment, personnel, and communication materials.

According to the definition by [15], satisfaction is the "fulfillment of one's wishes, expectations, or needs, or the pleasure derived". In line with the definition from Merriam Webster Dictionary [16], satisfaction defined as "a happy or pleased feeling because of something that you did or something that happened to you; the act of providing what is needed or desired". It is originated from the Old French as 'satisfier' and from Latin as 'satisfaction'. The earliest recorded use referred to the last part of religious penance after "contrition" and "confession": this involved fulfillment of the observance required by the confessor, in contrast with the current meaning 'fulfillment of one's own expectations'. 
Tsiros, et al. [17] defines customer satisfaction as “a person's feelings of pleasure or disappointment that result from comparing a product's perceived performance or outcome to expectations". Companies need to recognize that the customers vary in how they defined performance. Good delivery could mean early delivery, on-time delivery, or order completeness and two customers can report being "highly satisfied" for different reasons. One may be easily satisfied most of the time and the other might be hard to please but was please on this occasion [10]. Wise firms measure customer satisfaction regularly, because it is one key to customer retention. A highly satisfied customer generally stays loyal longer, buys more as the company introduces new and upgraded products, talks favorably to others about the company and its products, pays less attention to competing brands and is less sensitive to price, offers product or service ideas to the company, and costs less to serve than new customers because transactions can become routine [18].

Several recently published articles within the field of recording studio and its relation with marketing theory has been lacking. However, a few number of studies are collected which shows the current type of studies conducted by previous scholars. Watson and Beaverstock [19] studied the music recording industry from the point of view of 'transnational freelancing' of which more focusing on the phenomena of freelance labor in the music recording industry. Watson [20] had also discussed the idea of digital disruption and recording studio diversification in the digital age. This particular study is primarily concentrating on the diversification ideas of recording studio in the globalized era. David Pick, et al. [21] separately studied regarding the creative production process in recording studios and the making of a pop song. Based on the previous literature review conducted, indeed previous scholars that discuss the connection between marketing - in terms of customer satisfaction and service quality - and recording studio has been lacking. Hence, this study attempts to fill the gap of service quality and customer satisfaction in the music recording studio industry.

\section{METHOD AND HYPOTHESIS DEVELOPMENT}

The research took place and time in Bandung from December 2014 to March 2015. The research methodology in this study adapts the model from [22]. This methodology is used because it provides a systematic framework in determining the stages from the research background to the conclusion. In addition, the framework can also be adjusted by using the steps of marketing research according to [10]. The research is carried out by using qualitative and quantitative data collection. Several qualitative data observations method in this research are done by literature study, focus group discussions, and interviews. Literature study is done by observing information through the media such as text books, journals, and articles. In this research, literature study is used to find relevant theories, cases and previous researches to support this study, including finding basic variables of the service quality factors. Focus group discussion is done due to several technical reasons such as its easiness and other factors [23]. This technique involves organized discussion with three groups of individuals to gain information about their views and experiences of a topic. In this research, interview is used to observe the perceived and expected performance of a recording studio in qualitative terms to gain more understandings. According to Milena, et al. [24] the use of interview method is considered to be a solution in investigating.

Upon collecting basic measurement variables through qualitative study, the author designed the questionnaire for validity and reliability test. The questionnaire is derived from the previous qualitative study, and is quantified using four points Likert scale, ranging from strongly disagree to strongly agree. This preliminary test is conducted to 25 respondents to ensure that the questionnaire is valid and reliable. According to previous study by Tanuwijaya [25] the minimum sample respondents for validity and reliability test needed is 25 . The questionnaire method in this research is implemented to gather the primary data regarding the perceived performance of the customer along with the general satisfaction level of the customer. The statistical test is conducted using SPSS 16.0 software. Using the formula to obtain sample size from [26], it can be determined that by knowing the population size of 600 people on average per month, and error estimate of $10 \%$, the sample size gained from the formula is minimum 85 people, while on this research, 86 people are obtained as respondents. The sampling technique in this research is done through purposive sampling. Respondent profiles in this study must have made use of music studio at least two times previously. Questionnaire is designed with Bahasa Indonesia to ensure that most of the respondents who are Indonesian can understand clearly the point of each questions. These questionnaires are distributed through printed papers, and also through online forms.

This research emphasizes the importance of customer satisfaction in the service industry, specifically in recording studios. The reason is that nowadays, many companies are systematically measuring how well they treat customer, identifying the factors shaping satisfaction, and changing operations and marketing as a result [27]. If the performance falls short of expectations, the customer is dissatisfied. If it matches expectations, the customer is satisfied. If it exceeds expectations, the customer is highly satisfied or delighted [28]. The variables that are used to measure the service quality are the five dimensions of service quality: reliability $\left(\mathrm{X}_{1}\right)$, responsiveness $\left(\mathrm{X}_{2}\right)$, assurance $\left(\mathrm{X}_{3}\right)$, empathy $\left(\mathrm{X}_{4}\right)$, and tangible $\left(\mathrm{X}_{5}\right)$ as shown in Figure 1. The dependent variable $(\mathrm{Y})$ is the general customers' satisfaction throughout the experiences they had. 


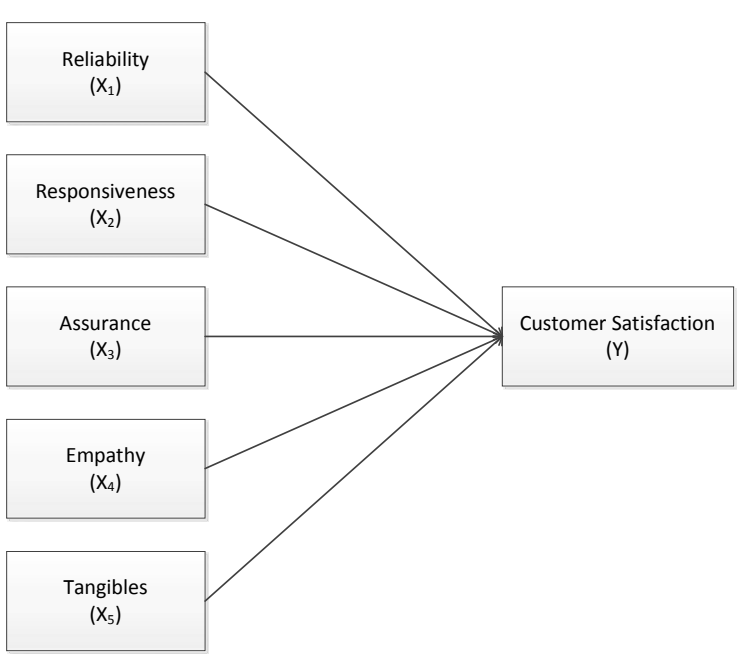

Fig. 1. Theoretical Framework

Based on the literature studies, the proposed hypothesis is written in the following forms:

- $\mathrm{H}_{1}$ : There is a relationship between reliability dimensions with the customers' satisfaction.

- $\mathrm{H}_{2}$ : There is a relationship between responsiveness dimensions with the customers' satisfaction.

- $\mathrm{H}_{3}$ : There is a relationship between assurance dimensions with the customers' satisfaction.

- $\mathrm{H}_{4}$ : There is a relationship between empathy dimensions with the customers' satisfaction.

- $\mathrm{H}_{5}$ : There is a relationship between tangible dimensions with the customers' satisfaction.

\section{ANALYSIS AND DISCUSSION}

Service quality determinants are adapted from Parasuraman, et al. [8] which is reviewed with previous studies and also discussed through focus group method with the experts in this particular field. The experts in this study are those with experiences more than five years in the music industry. These experts are ranging not only from musicians with different instruments, and also the organizers, who have previously involved and practiced in various music studios. To ensure that the questionnaire is reliable and valid, reliability test and validity test was conducted. In the first stage of the test, 25 questionnaires were distributed. In the first stage of the test, there were some factors considered as not valid and not reliable. Hence the author made several adjustments to the questionnaire. In the second stage of the test, the revised questionnaires are distributed to 25 respondents. Upon the revision, all the six parameters are considered valid and reliable according to the statistical test. Cronbach's alpha is the index of which the author can justify whether the questionnaire is reliable. This coefficient varies from zero to one, and a value of 0.6 or less generally indicates unsatisfactory internal consistency reliability [29]. Below is the analysis for each research indicators for the five dimensions of service quality $\left(\mathrm{X}_{1}, \mathrm{X}_{2}, \mathrm{X}_{3}, \mathrm{X}_{4}\right.$, and $\left.\mathrm{X}_{5}\right)$ and the satisfaction level (Y).

\begin{tabular}{|l|l|l|l|}
\hline \multicolumn{1}{|c|}{ Parameters } & $\begin{array}{c}\text { Cronbach's } \\
\text { Alpha }\end{array}$ & $\begin{array}{c}\text { Measurement } \\
\text { Variables }\end{array}$ & Reliability \\
\hline Satisfaction & 0.892 & 3 & Reliable \\
\hline Reliability & 0.692 & 3 & Reliable \\
\hline Responsiveness & 0.85 & 3 & Reliable \\
\hline Assurance & 0.836 & 4 & Reliable \\
\hline Empathy & 0.722 & 3 & Reliable \\
\hline Tangible & 0.73 & 5 & Reliable \\
\hline
\end{tabular}

The measurement variables as shown in Table I show that all parameters are reliable to be distributed to the respondents. Therefore, validity test need to be conducted to find out every parameter's validity. Table II shows the validity of every question parameter which is shown by the corrected item-total correlation that needs to be 0.3 above to be considered valid.

\begin{tabular}{|c|c|c|c|}
\hline & TABLE II. & ITY TEST & \\
\hline $\begin{array}{l}\text { SERVICE } \\
\text { QUALITY } \\
\text { FACTORS }\end{array}$ & $\begin{array}{l}\text { QUESTION } \\
\text { PARAMETER }\end{array}$ & $\begin{array}{l}\text { CORRECTED } \\
\text { ITEM-TOTAL } \\
\text { CORRELATION }\end{array}$ & VALIDITY \\
\hline Satisfaction & $\begin{array}{l}\text { Overall, I am satisfied } \\
\text { with the service } \\
\text { provided by the studio. }\end{array}$ & 0.689 & Valid \\
\hline Satisfaction & $\begin{array}{l}\text { I would likely come } \\
\text { again in the future to } \\
\text { the studio }\end{array}$ & 0.848 & Valid \\
\hline Satisfaction & $\begin{array}{l}\text { I would likely } \\
\text { recommend my friends } \\
\text { to come to the studio }\end{array}$ & 0.841 & Valid \\
\hline Reliability & $\begin{array}{l}\text { Employees of the } \\
\text { studio are able to } \\
\text { handle problems } \\
\text { accurately. }\end{array}$ & 0.546 & Valid \\
\hline Reliability & $\begin{array}{l}\text { Employees of the } \\
\text { studio are competent } \\
\text { to conduct the tasks } \\
\text { assigned. }\end{array}$ & 0.708 & Valid \\
\hline Reliability & $\begin{array}{l}\text { Employees of the } \\
\text { studio have sufficient } \\
\text { experiences (minimum } \\
1 \text { year) to conduct the } \\
\text { tasks assigned }\end{array}$ & 0.356 & Valid \\
\hline $\begin{array}{l}\text { Responsiven } \\
\text { ess }\end{array}$ & $\begin{array}{l}\text { Employees of the } \\
\text { studio give prompt } \\
\text { service to customers. }\end{array}$ & 0.847 & Valid \\
\hline $\begin{array}{l}\text { Responsiven } \\
\text { ess }\end{array}$ & $\begin{array}{l}\text { Employees of the } \\
\text { studio are always } \\
\text { willing to help } \\
\text { customers. }\end{array}$ & 0.586 & Valid \\
\hline $\begin{array}{l}\text { Responsiven } \\
\text { ess }\end{array}$ & $\begin{array}{l}\text { Employees of the } \\
\text { studio are never too } \\
\text { busy to respond to } \\
\text { customers }\end{array}$ & 0.747 & Valid \\
\hline Assurance & $\begin{array}{l}\text { Customers trust the } \\
\text { employees of the } \\
\text { studio. }\end{array}$ & 0.736 & Valid \\
\hline Assurance & $\begin{array}{l}\text { Customers feel safe in } \\
\text { their transactions with } \\
\text { the employees of the } \\
\text { studio. }\end{array}$ & 0.708 & Valid \\
\hline Assurance & Employees of the & 0.808 & Valid \\
\hline
\end{tabular}


TABLE II. VALIDITY TEST

\begin{tabular}{|c|c|c|c|}
\hline $\begin{array}{l}\text { SERVICE } \\
\text { QUALITY } \\
\text { FACTORS }\end{array}$ & $\begin{array}{l}\text { QUESTION } \\
\text { PARAMETER }\end{array}$ & $\begin{array}{c}\text { CORRECTED } \\
\text { ITEM-TOTAL } \\
\text { CORRELATION }\end{array}$ & VALIDITY \\
\hline & studio are polite. & & \\
\hline Assurance & $\begin{array}{l}\text { Employees of the } \\
\text { studio are on time } \\
\text { when working. }\end{array}$ & 0.478 & Valid \\
\hline Empathy & $\begin{array}{l}\text { Their employees are } \\
\text { willing to maintain } \\
\text { good relationship with } \\
\text { the customer. }\end{array}$ & 0.699 & Valid \\
\hline Empathy & $\begin{array}{l}\text { The studio provides } \\
\text { convenient working } \\
\text { hours. }\end{array}$ & 0.454 & Valid \\
\hline Empathy & $\begin{array}{l}\text { The studio is able to } \\
\text { maintain regular } \\
\text { feedback from the } \\
\text { customer. }\end{array}$ & 0.504 & Valid \\
\hline Tangible & $\begin{array}{l}\text { The studio has up-to- } \\
\text { date-equipment. }\end{array}$ & 0.326 & Valid \\
\hline Tangible & $\begin{array}{l}\text { The studio physical } \\
\text { facilities are visually } \\
\text { appealing. }\end{array}$ & 0.447 & Valid \\
\hline Tangible & $\begin{array}{l}\text { The studio is } \\
\text { comfortable to be } \\
\text { utilized by customers. }\end{array}$ & 0.631 & Valid \\
\hline Tangible & $\begin{array}{l}\text { The studio provides } \\
\text { website to facilitate } \\
\text { information for distant } \\
\text { customers. }\end{array}$ & 0.691 & Valid \\
\hline Tangible & $\begin{array}{l}\text { The equipment } \\
\text { provided by The studio } \\
\text { is regularly } \\
\text { maintained. }\end{array}$ & 0.418 & Valid \\
\hline
\end{tabular}

As shown in Table II, all the variables for service quality factors and its measurements are considered valid (>0.3). Thus, this questionnaire can be considered valid and reliable to be used to model the multiple regressions for data analysis. Profile of the respondents varies from different types of customer. From the Table III it can be seen that most of the respondents are male with the percentage of $73.3 \%$ and Table IV shows that the age of the respondents is dominated by the people in their 20 to 30 with $65.1 \%$. This shows that the studio is attended by mostly teenagers and young adults. This finding is in accordance with the observations and information gathered during the discussions and interviews to the studio customers of whom they use the studio for recording, festivals at schools, and band competitions which is mostly practiced by this category of ages.
TABLE III. GENDER

\begin{tabular}{|l|l|}
\hline \multicolumn{1}{|c|}{ Gender } & Percent \\
\hline Total & 100 \\
\hline
\end{tabular}

TABLE IV. AGE

\begin{tabular}{|l|l|}
\hline \multicolumn{1}{|c|}{ Age } & \multicolumn{1}{c|}{ Percent } \\
\hline$<20$ & 9.3 \\
\hline $20-30$ & 65.1 \\
\hline $31-40$ & 20.9 \\
\hline $41-50$ & 4.7 \\
\hline Total & 100 \\
\hline
\end{tabular}

TABLE V. LAST EDUCATION

\begin{tabular}{|l|l|}
\hline \multicolumn{1}{|c|}{ Last Education } & \multicolumn{1}{c|}{ Percent } \\
\hline Diploma & 14 \\
\hline High School & 37.2 \\
\hline Graduate & 2.3 \\
\hline Undergraduate & 46.5 \\
\hline Total & 100 \\
\hline
\end{tabular}

TABLE VI. MONTHLY INCOME

\begin{tabular}{|l|l|}
\hline \multicolumn{1}{|c|}{ Monthly Income } & \multicolumn{1}{c|}{ Percent } \\
\hline$<2$ Million & 45.3 \\
\hline$>10$ Million & 8.1 \\
\hline 2 - 4 Million & 12.8 \\
\hline 4 - 6 Million & 12.8 \\
\hline 6 - 8 Million & 10.5 \\
\hline 8 - 10 Million & 10.5 \\
\hline Total & 100 \\
\hline
\end{tabular}

TABLE VII. TOTAL MUSIC StUdiO VISITS

\begin{tabular}{|l|l|}
\hline \multicolumn{1}{|c|}{ Total visits } & \multicolumn{1}{c|}{ Percent } \\
\hline$>4$ & 29.1 \\
\hline 2 to 3 & 26.7 \\
\hline 3 to 4 & 44.2 \\
\hline Total & 100 \\
\hline
\end{tabular}

TABLE VIII. RESPONDENTS PROFESSION

\begin{tabular}{|l|l|}
\hline \multicolumn{1}{|c|}{ Profession } & Percent \\
\hline Freelancer & 4.7 \\
\hline Housewife & 1.2 \\
\hline Musician & 1.2 \\
\hline State Owned Employee & 1.2 \\
\hline Civil Employee & 7.0 \\
\hline Private Employee & 27.9 \\
\hline Students & 45.3 \\
\hline
\end{tabular}


TABLE VIII. RESPONDENTS PROFESSION

\begin{tabular}{|l|l|}
\hline \multicolumn{1}{|c|}{ Profession } & Percent \\
\hline Entrepreneur & 8.1 \\
\hline Professional & 2.3 \\
\hline Artist & 1.2 \\
\hline Total & 100 \\
\hline
\end{tabular}

In the field of education, Table $\mathrm{V}$ presents the percentages of the last education finished by the customer, of which $83.7 \%$ are from students and undergraduates. On average, Table VI shows that the monthly income distribution spans from each of the category, yet still dominated by people with the income of two million rupiahs a month. Most of the respondents with $44.2 \%$ have come to music recording studio more than three times as illustrated in Table VII. Table VIII shows the category of profession on respondents. This indicates that the respondents should have sufficient observations and experiences in using the studio to determine their satisfaction level. In order to determine the relationship between customers' satisfaction and service quality among its indicators, the author uses the mean number for each of every question shown by its indicator.

\begin{tabular}{|l|l|l|l|l|c|}
\multicolumn{1}{c|}{ TABLE IX. } \\
\hline & $\begin{array}{c}\text { Sum of } \\
\text { Squares }\end{array}$ & df & $\begin{array}{c}\text { Mean } \\
\text { Square }\end{array}$ & F & Sig. \\
\hline Regression & 19.631 & 5 & 3.926 & 32.602 & $.000^{\mathrm{a}}$ \\
\hline Residual & 9.634 & 80 & 0.12 & & \\
\hline Total & 29.265 & 85 & & & \\
\hline
\end{tabular}

a. a. Predictors: (Constant), AvgTang, AvgAssurance, AvgResp, AvgEmpath, AvgRel

$$
\text { b. b. Dependent Variable: AvgSatsf }
$$

According to the analysis by SPSS 16.0, Table IX illustrates the coefficients for every service quality factors which are determined by the value of Unstandardized B. Hence, the multiple regression equation is $\mathrm{Y}=0.549 \mathrm{X}_{1}-$ $0.043 \mathrm{X}_{2}-0.012 \mathrm{X}_{3}-0.142 \mathrm{X}_{4}+0.4 \mathrm{X}_{5}-0.002$. On the other hand, the R-Square value shows the coefficient of multiple determinations which resulted 0.671 . This means, about $67.1 \%$ of the variation in the customer satisfaction is explained by the five service quality factors. Using a level of significance $\alpha$, the decision rule is to reject $\mathrm{H}_{0}$ if $\mathrm{F}_{\text {test }}>\mathrm{F}_{\alpha} /$ $\mathrm{F}_{\text {critical }}$ or p-value $<0.1$; otherwise do not reject $\mathrm{H}_{0}$. According to the ANOVA analysis on Table $\mathrm{X}$ and referring to the hypothesis, the calculation resulted $\mathrm{p}$-value less than 0.1 and $\mathrm{F}_{\text {test }}>\mathrm{F}_{\alpha} /$ Fcritical. Therefore, we reject $\mathrm{H}_{0}$ and there exists enough evidence to conclude that at least one of the predictors is useful for predicting customer satisfaction.

To determine the existence of a significant linear relationship between each variable, t-test for the slope can be used to determine whether the hypothesis above is statistically significant. Using a level of significance $\alpha$, the decision rule is to Reject $\mathrm{H} 0$ if $\mathrm{t}_{\text {test }}>\mathrm{t}_{\alpha}$ or $\mathrm{p}$-value $<0,1$; otherwise do not reject $\mathrm{H} 0$. According to the Coefficient Table and referring to the hypothesis, the $t_{\text {test }}$ resulted $\mathrm{p}$-value less than 0.1 for Reliability and Tangible. On the other hand, the $t_{\text {test }}$ has resulted $p$-value above 0.1 for Responsiveness, Assurance and Empathy.

TABLE $X . \quad$ COEFFICIENTS

\begin{tabular}{|c|c|c|c|c|c|}
\hline \multirow{2}{*}{ Model } & \multicolumn{2}{|c|}{$\begin{array}{c}\text { Unstandardized } \\
\text { Coefficients }\end{array}$} & \multirow{2}{*}{$\begin{array}{c}\text { Standardized } \\
\text { Coefficients } \\
\text { Beta } \\
\end{array}$} & \multirow{2}{*}{$\mathbf{t}$} & \multirow{2}{*}{ Sig. } \\
\hline & $B$ & $\begin{array}{c}\text { Std. } \\
\text { Error }\end{array}$ & & & \\
\hline (Constant) & -0.002 & 0.271 & & $\begin{array}{l}- \\
0.007\end{array}$ & 0.994 \\
\hline AvgRel & 0.549 & 0.119 & 0.457 & 4.606 & 0 \\
\hline AvgResp & -0.043 & 0.079 & -0.044 & -0.55 & 0.584 \\
\hline AvgAssurance & -0.012 & 0.144 & -0.01 & $\overline{0} .083$ & 0.934 \\
\hline AvgEmpath & 0.142 & 0.105 & 0.125 & 1.358 & 0.178 \\
\hline AvgTang & 0.4 & 0.063 & 0.468 & 6.392 & 0 \\
\hline
\end{tabular}

Therefore, for the variable of Reliability and Tangible, we reject $\mathrm{H}_{0}$ and there exists enough evidence to conclude that the slope of the Reliability and Tangible are not zero and, these variables are useful as a predictors of customers' satisfaction. However, we do not reject $\mathrm{H}_{0}$ for Responsiveness, Assurance and Empathy as there is insufficient evidence that these variables are useful for predictors of customers' satisfaction. According to the above finding, it can be seen that the service quality of music studio Bandung area is determined by two aspects which are reliability and tangible factors. This does not mean that the three other factors are not important, since based on the statistical analysis, the author does not reject the null hypothesis. However, the author can conclude in this study that reliability and tangible are the two main factors that have significant effect towards customers' satisfaction. In this study, reliability means the ability to perform the promised service dependably and accurately. Tangible, is the appearance of physical facilities, equipment, personnel, and communication materials. Based on the previous experiences of the author in utilizing music studio, these two factors indeed play important role in terms of quality and satisfaction. Customers that are utilizing music studio might have come from different background and different needs. Therefore, the staff of the studio shall be able to handle the problems very well to boost the perceived quality by the customers, in terms of reliability. In terms of tangibles, physical attributes will be the focus on music studio which might need evaluation and provide room for improvements. Very often, based on the previous experiences and observation, customers tend to complaint regarding the equipment which are not maintained regularly, dusty room, uncomfortable waiting room or toilet, which are the symptoms that point the tangible factors. Hence, this tangible factor will need more attention to improve the service quality of the studio.

Three other insignificant factors do not mean that they are not important, but on this study it is concluded that these factors do not contribute significantly to the service quality. Responsiveness, assurance and empathy may have its own portion to the service quality of music studio. Based on the previous experiences and observations, responsiveness might 
not become central part of service quality due to the nature of the business. The staffs of the studio only handle one customer per session, which make them available and responsive in handling customer. Particular case might happen when the staffs are too busy to help customer, but this seldom happen in music studio as it is almost $95 \%$ of the time that there is always one available staff for one active customer. Generally, mutual trust between customer in transaction (purchasing the service, booking) is not a main problem because most studios will let the customer to use the service first, then pay the price when the session end. Hence, in terms of assurance - security in payment or booking - is not a main problem. Empathy, may have only little role in promoting service quality. Usually, staff of the studio does not need to provide such five-star hotel service in terms maintaining relationships and showing empathy / exclusive respect to the customers. Just and friendly welcome is sufficient to show respect and willingness to serve the customers. Still, maintaining good relationship is vital and this can result in repeat order for the customer due to the good relationship built between customer and the staffs.

\section{CONCLUSION}

First, based on the above findings the author concludes that in music studio recording industry, service quality has significant relationship to customers' satisfaction. Among the five factors in service quality, Reliability and Tangible factors are the most significant factors to customers' satisfaction, while Responsiveness, Assurance and Empathy do not statistically affect customers' satisfaction. Tangibles are the appearance of physical facilities, equipment, personnel, and communication materials which include modern equipment, visually appealing facilities, and employees who have a neat and professional appearance, visually appealing materials associated with the service. Reliability is the ability to perform the promised service dependably and accurately. The attributes include providing service as promised, dependability in handling customers' service problems, performing services right the first time, providing services at the promised time, maintaining errorfree records, employees who have the knowledge to answer customers' questions. Hence, based on the findings these two aspects need more attention for strategic long term investment. Second, it is recommended for music recording studios to emphasis its investment and marketing strategy on the tangibles. This does not mean to regularly update and buy for new musical equipment but rather to provide adequate equipment for the customers in every aspect. This includes musical instruments, amplifiers, speakers, headphones, microphones, room acoustic design, ambience, and lighting. Maintenance is also an important aspect to ensure that the qualities of these tangibles are taken care well. Third, the reliability aspect on this industry is focused on the quality of the staffs. Every customer will ask for the staffs if there is any problem occurred. The ability of the staff to give guidance and answers are critical in this industry. Therefore, focus on the training and development of the staff is very important. Improving the studio services shall be managed from every aspect which spans from welcoming guests, accepting reservations, maintaining relationship with customers, studio maintenance, digital recording, sound engineering, and music production. Indonesian music industry has never stopped producing through different eras. Music recording studios will contribute important role in Indonesia's music industry for producing artist, new comers, and supporting local bands in local festivals. Focus on the quality will help studios to strive and survive in this business. This will contribute to more profitability in times of global uncertainties. This research however has some limitations mainly in total number of samples and limited location of research. Future research is suggested to be observing more studios in multiple places, with greater amount of samples. Nevertheless, this study can give preliminary insights regarding the building blocks of service quality in music recording studio industry, particularly in Indonesia.

\section{REFERENCES}

[1] A. Watson, "'Running a studio's a silly business': work and employment in the contemporary recording studio sector," Area, vol. 45, pp. 330-336, 2013.

[2] A. Ginanjar and D. Waraditya. (2014). Industri Musik Kuasai 85\% Pasar Industri Kreatif. Available:

http://lifestyle.bisnis.com/read/20140930/225/2612 14/-industri-musik-kuasai-85-pasar-industri-kreatif

[3] Antarariau.com. Industri Musik Hasilkan Rp 5.237 Triliun Untuk PDB. Available: http://www.antarariau.com/berita/40696/--industrimusik-hasilkan-rp5237-triliun-untuk-pdb

[4] Artsoundstudio.com. Testimonials. Available: http://www.artsoundstudio.com/testimonials.html

[5] H. Nugroho. (2011). Lokananta, Antara Hidup dan Mati. Available: http://www.tempo.co/read/news/2011/05/09/161333 260/Lokananta-Antara-Hidup-dan-Mati

[6] K. Pea. (2011, 2014). Musik Cepat dan Gairahnya Anak Muda. Available: http://www.kikipea.com/2011/04/musik-cepat-dangairahnya-anak-muda_07.html

[7] A. Seruni, "Peran Sound Engineer Dalam Meningkatkan Kualitas Produksi Di Rumah Produksi Suara: Basement Music and Recording Studio," Bachelor, Business School, Bina Nusantara University, 2011.

[8] A. Parasuraman, V. A. Zeithaml, and L. L. Berry, "A Conceptual Model of Service Quality and Its Implications for Future Research," Journal of Marketing, vol. 49, pp. 41-50, 1985.

[9] P. Alexander, "New Technology and Market Structure: Evidence from the Music Recording Industry," Journal of Cultural Economics, vol. 18, pp. 113-123, 1994.

[10] P. Kotler and K. Keller, Marketing Management: Fourteenth Edition. Essex: Pearson Education Limited, 2012. 
[11] G. Suarez, "Three Experts on Quality Management: Philip Crosby, Edwards Deming, Joseph Juran," Total Quality Leadership Office Publication, 1992.

[12] T. Chandrupatla, Quality and Reliability in Engineering: First Edition: Cambridge University Press, 2009.

[13] R. Lewis and B. Booms, "The Marketing Aspects of Service Quality," Chicago, 1983.

[14] P. Asubonteng, K. J. Mccleary, and J. E. Swan, "SERVQUAL revisited: A critical review of service quality," The Journal of Services Marketing, vol. 10, pp. 62-81, 1996.

[15] Oxford Dictionaries, ed, 2016.

[16] Merriam Webster Dictionary, ed, 2016.

[17] M. Tsiros, V. Mittal, and W. T. Ross, "The Role of Attributions in Customer Satisfaction: A Reexamination," Journal of Consumer Research, vol. 31, pp. 476-483, 2004.

[18] C. Homburg, N. Koschate, and W. D. Hoyer, "Do Satisfied Customers Really Pay More? A Study of the Relationship between Customer Satisfaction and Willingness to Pay," Journal of Marketing, vol. 69, pp. 84-96, 2005.

[19] A. Watson and J. V. Beaverstock, "Transnational freelancing: Ephemeral creative projects and mobility in the music recording industry," Environment and Planning A, p. $0308518 X 16641412,2016$.

[20] A. Watson, "5. Digital disruption and recording studio diversification: changing business models for the digital age," Business Innovation and Disruption in the Music Industry, p. 95, 2016.

[21] D. P. W. David Pick, Professor Julia Connell, D. Dr Louis Andre Geneste, and J. M. Gander, "Situating creative production: recording studios and the making of a pop song," Management Decision, vol. 53, pp. 843-856, 2015.

[22] U. Sekaran and R. Bougie, Research Method for Business: A Skill Building Approach, 5 ed. East Lothian: John Wiley and Sons Limited, 2010.

[23] A. Gibbs, Social Research Update: Focus Groups. Guildford: University of Surrey, 1997.

[24] Z. R. Milena, G. Dainora, and S. Alin. (2008). Qualitative Research Methods: A Comparison between Focus-Group and In-Depth Interview. Available:

https://core.ac.uk/download/files/153/6257621.pdf

[25] P. Tanuwijaya, "Customer Satisfaction Analysis Using Servqual Method: A Case Study of Bhinneka.com," Master, Binus Business School, 2009.

[26] T. Yamane, Statistics: An Introductory Analysis. New York: Harper \& Row, 1973.

[27] N. Morgan, "Marketing and Business Performance," Journal of the Academy of Marketing Science, vol. 40, pp. 102-119, 2012.
[28] P. Kopalle and L. Donald, "Setting Quality Expectations When Entering a Market: What Should the Promise be," Journal of Marketing Services, vol. 25, pp. 8-24, 2006.

[29] N. Malhotra, Marketing Research: An Applied Orientation, 6 ed. New Jersey: Prentice Hall Inc., 2010. 